\title{
Integrating improved beekeeping as economic incentive to community watershed management: The case of sasiga and Sagure districts in Oromiya region, Ethiopia
}

\section{Tolera Kumsa Gemeda}

Holeta Bee Research Centre, Oromia Agriculture Research Institute, Holeta, Ethiopia

\section{Email address:}

tolekume@yahoo.com

\section{To site this article:}

Tolera Kumsa Gemeda. Integrating Improved Beekeeping as Economic Incentive to Community Watershed Management: The Case of Sasiga and Sagure Districts in Oromiya Region, Ethiopia. Agriculture, Forestry and Fisheries. Vol. 3, No. 1, 2014, pp. 52-57. doi: 10.11648/j.aff.20140301.19

\begin{abstract}
Beekeeping gives local people economic incentive for the retention of natural habitats, and is an ideal activity in watershed conservation program. A project was carried out in sagure watershed in Arsi Zone and Sasiga watershed in East Wollega Zone. The objective is to introduce improved beekeeping as the incentive for watersheds conservation. Data were collected through interviews, observation, bee forage assessment, improved beekeeping implementation and honey production. After training, beekeepers highly acquainted in improved beekeeping management and this resulted in increased honey production simultaneously increased local initiative in watershed rehabilitation and protection. Beekeepers maintained diverse honeybee floral resources designed to achieve maximum honey production and watershed rehabilitation. The study identified that watershed integrated improved beekeeping is important as a strong economic incentives that integrate watershed conservation with economic development from honey and beeswax production. Efforts of the government are highly required to organize landless and marginalized peoples by providing them with the necessary beekeeping technologies and inputs to ensure maximum honey production while promoting watershed rehabilitation and conservation.
\end{abstract}

Keywords: Beekeeping, Watershed, Conservation, Honey

\section{Introduction}

Dependence on subsistence agriculture has depleted the natural vegetation and has been less effective in improving the living standards of communities. Implementation of livelihood activities through a strategic mix of community participation in conservation is very essential. Improved beekeeping is identified as strong profitable economic incentive to promote conservation and rehabilitation in the face of demand for cultivated land (Munthali and Mughogho, 1992). Beekeeping is taken into account when the economic importance of trees being calculated (Debisa, 2006; Albers and Robinson, 2011).

Beekeeping preserves nature, agriculture, sustains livelihoods, and provides food security through, increasing beekeepers participation in regeneration of different bee forage species and at the same time increasing flowering plant and crop pollination (Somerville, 1997; Brown, 2001; Lietaer, 2009; Bradbear, 2009). Despite its important roles, the potential of beekeeping is apparently not exploited and quantified as economic incentive in forestry and watershed conservation through harvesting of organic bee product. Bee products provide health, high-nutrient food, safe medicines and raw material for pharmaceutics and cosmetics industries (Lietaer, 2009). It is proved as a reliable source of income generation for small and marginal farmers, women and other vulnerable society who are depending on charcoal production. When beekeepers are supported with improved beekeeping technologies and have access to good markets for their products, they are motivated to support local conservation efforts.

Community motivation to conserve and rehabilitate biodiversity increases when households are benefited from the commercial value such as honey and beeswax into their livelihood strategies (Munthali and Mughogho, 1992; Holzschuh et al, 2007 Paraïso et al 2012). Improving the 
existing watershed resource management through categorization of land-use patterns is the priorities issues identified by Agricultural Sector Support Project (ASSP) in potential watershed areas. The objective is intended to reach landless and marginalized people to access watershed through implementing improved beekeeping for maximum honey production. This is an area of investigation that has been neglected and yet holds significant potential for future sustainable forestry and watershed management initiatives.

\section{Methodology}

\subsection{Study Site}

Two areas designated as regionally important watershed, namely Sasiga watershed in East Wollega Zone and Sagure watershed in Arsi Zone of Ethiopia were selected for the study. The research was undertaken in collaboration with Agricultural Sector Support (ASSP) project and Holeta Bee Research Center.

\subsection{Methods}

The research technique is participatory action research designed to integrate improved beekeeping as economic incentive to develop sustainable watershed rehabilitation. A questionnaire survey was used to gather information on beekeepers socio-economic. The questionnaire comprised both structured and open-ended questions on beekeepers watershed resource utilization, awareness of beekeepers on watershed conservation, honey production trend and income generated from bee product selling. Thirty people involved in traditional and improved beekeeping were randomly chosen in watersheds and interviewed following (Saville and Upadhaya, 2000).

Skills and knowledge gaps on beekeeping was assessed and identified in watersheds. Practical training on honeybee transferring from traditional to improved hives, seasonal honeybee colony manipulation and intermediate beehive construction were carried out. Implementation and demonstration of watershed-beekeeping integrated was done for easy to follow up and gather important information from improved beehives. The software (SPSS) and descriptive statistics were used to analyze the data.

\section{Result}

\subsection{Resource Utilization of Watershed Beekeepers}

Land holdings vary considerably among the watershed community, ranging from nil to as high as 6 hectares. Agriculture Sector Support Project (ASSP) supports the watershed communities through provision of improved agricultural and beekeeping technologies. Only $28.5 \%$ of watershed communities engaged in traditional beekeeping and depended heavily on watersheds for their social and economic well-being. Analysis of landholdings of beekeepers revealed that, about 25\% in Sagure and $8 \%$ in Sasiga watersheds beekeepers do not own any land and depending on honey production and other off-farm activities without harming the watershed environment.

Interaction was made with traditional beekeepers to find the watershed resources utilization and trend of honey production. Most (92\%) of beekeepers in watershed have a norm to maintain indigenous tree remnants around their homestead and always interested to plant shrubs and trees important for honeybees to forage. They are conscious to value watersheds for hanging beehive, pollen and nectar source and calculating the economical values of each flowering trees in terms of honey yield. However, it is difficult to estimate the extent of traditional beekeeping to which it contributed to the livelihoods of the watershed user groups.

All beekeepers in watersheds have the ability to predict watershed potential in terms of amount of honey production, ecological potential to sustain honeybee colonies and number of honeybee swarms trapped in the new traditional hive. After project intervention, beekeepers motivated to protect the watershed vegetation and through increasing household income from the sale of honey and beeswax in local markets.

\subsection{Skill Development on Improved Beekeeping}

The major constraints to effective honey production among the beekeepers respondents were inadequate skills of seasonal bee management (81\%), high cost of bee equipment $(65 \%)$, poor processing facilities $(34.7 \%)$, and honeybee pests $(29.0 \%)$. Most of the constraints indicated by the beekeepers were associated with inadequate skills on improved beekeeping. The project was organized and mobilized watershed beekeepers into workable groups to increase honeybee production through providing of practical beekeeping training and implementation.

Improved beekeeping training on procedures of honeybee colony transfer to improved bee hives, colony inspection, honeybee swarm control, techniques on detecting matured honey, identification of bee pest and disease was carried out. Seasonal honeybee management based on the dynamics of watersheds nectar flow was identified.

Two beekeeping user groups, each consisting of 12 individuals were formed in watersheds to implement and demonstrate improved beekeeping to ensure maximum production of honey. The beekeeping user group acquainted to manage the bee colonies in improved hives according to the seasonal variation of honeybee forage flowering. 


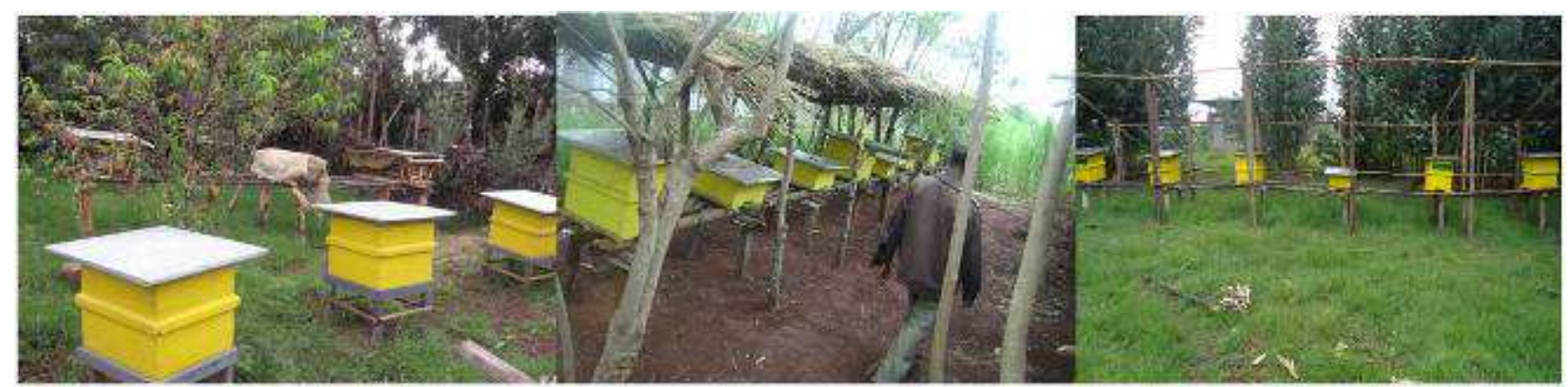

Figure 1. Beekeeping site at communal watershed.

The beekeeping user groups have established 12 modern beehives and 8 intermediate hives at each watershed and had identified two successful harvests (June and November). Amount of honey harvested was increased after project intervention $(14.8 \mathrm{~kg}$ in intermediate hive and $21.2 \mathrm{~kg}$ in modern hive per harvest compared to $5 \mathrm{~kg}$ in traditional hives). The increased honey yield provided beekeeping user groups with an alternative source of income compared to the chopping down of watershed trees to sell as charcoal. The project increased the incomes of watershed beekeepers by $35 \%$ from the sale of honey. Most
(71\%) of watershed beekeepers established their own improved beehives at their home and each harvested an average of 17.2 and $24.6 \mathrm{kgs}$ of honey from intermediate and modern beehives respectively. The expected yields of honey for future tends to the better in which the floral resources such as trees, shrubs and herbs are increasing as worked by different teams of watershed members. According to the survey, revenues from honey production, $37 \%$ is invested in improved seeds purchase, $25 \%$ in medicine, $23 \%$ in school fees for children and, $15 \%$ improve housing.
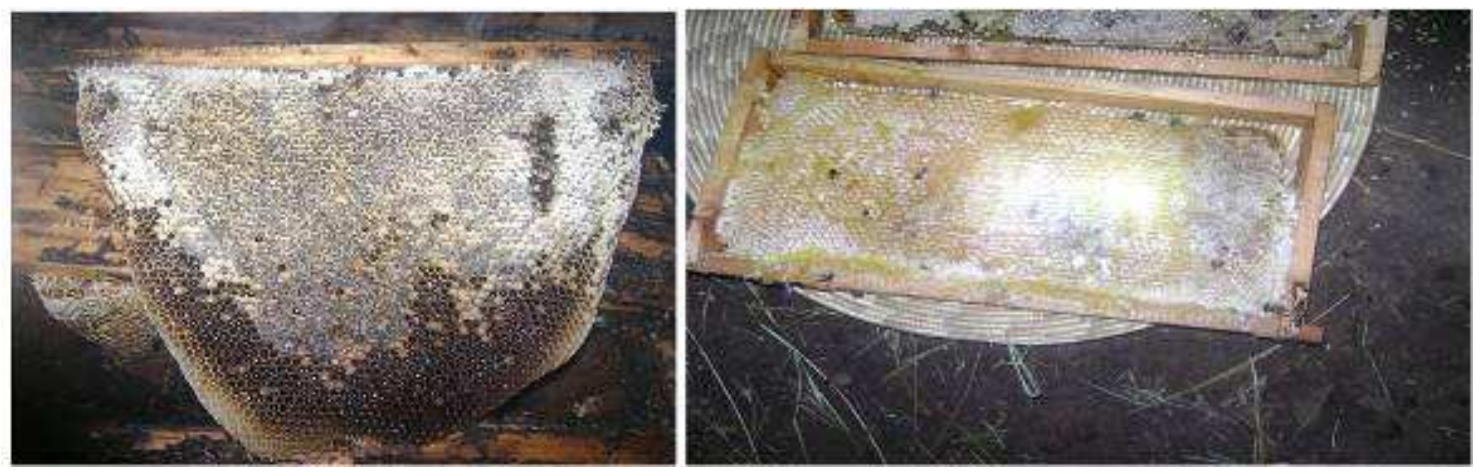

Figure 2. Honey harvested from intermediate and modern hives in watersheds.

\subsection{Beekeeping as Tools to Watershed Conservation}

Beekeepers in watersheds have special characteristic to maintain and recognize trees, shrubs and herbaceous important for honey and beeswax production (Alemtsehay, 2011). Various plants were blossoming in different seasons and honeybees visited these plants for nectar and pollen sources. Based on the source, 16 plant species were identified as important bee flora in watershed areas (table 1). These bee forage species planted and maintained by beekeepers in horticultural, agro-forestry, and woodlot and as life fences important for honey production and watershed conservation. This project improved watershed management of nearly 37 hectares and indirectly benefited 100 people who live in watersheds. 50,000 different bee forage seedlings at each watershed were propagated and distributed for watershed beekeepers with the aim to increase the honey production and indirectly enhance watershed conservations.

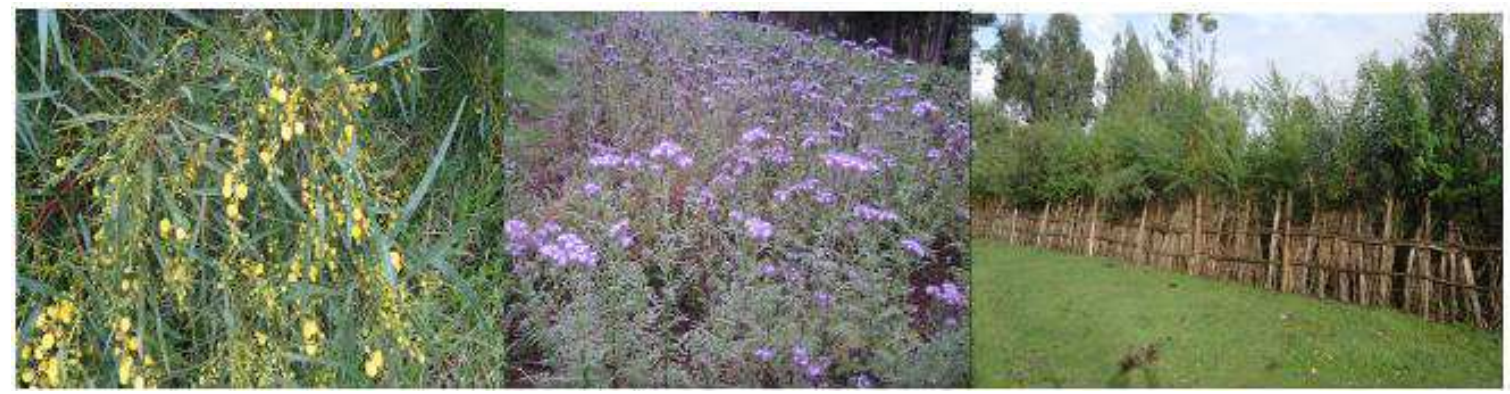

Figure 3. Bee forage propagated and maintained in watershed communities. 
Diversification of cropping systems team such as vegetables, legumes, oilseeds, and forage crops in watershed improved the rainwater harvesting capacity and the impacts on environmental resources (Adugna, 2002). Crop varieties planted in watershed observed as major honeybee forage and important to maximize honey yield and spread the farmer's economic risk. Moreover, the crop growers benefited from the pollination services of the honeybees indirectly but not yet quantified. A mixture of different weedy species maintained between crop boarders and uncultivated land of watershed contributed as major honeybee forage, rain water harvesting, watershed biodiversity conservation and climate adaption as well.

Table 1. Major flowering trees, shrubs and weeds grown in watersheds.

\begin{tabular}{|c|c|c|c|}
\hline & Major species name & Uses & Dominant \\
\hline 1 & Vernonia amygdalina & $\begin{array}{l}\text { A very useful shrubs important for live fence, animal feed } \\
\text { and major dearth period bee forage (January) }\end{array}$ & In both watersheds \\
\hline 2 & Eucalyptus camaldulensis & Fuel wood and major bee forage flowering whole year round & In both watersheds \\
\hline 3 & Eucalyptus globulus & $\begin{array}{l}\text { Fuel wood, pole for constricting houses, live fence and long- } \\
\text { term major bee forage (April to June) }\end{array}$ & In both watersheds \\
\hline 4 & Croton macrostachys & $\begin{array}{l}\text { Agro-forestry plant, used as fuel wood and major bee forage } \\
\text { flowered from (April to May) }\end{array}$ & In Sasiga watershed \\
\hline 5 & Grevillea robusta & Widely planted as live fence and major bee forage & In both watersheds \\
\hline 6 & Acacia abyssinica & Agro-forestry, animal feed, fuel wood and major bee forage & In both watersheds \\
\hline 7 & Acacia decurrens & Live fences, fuel, major bee forage plant & In Sagure watershed \\
\hline 8 & Cordia africana & Honeybee flower and live fence & In Both watersheds \\
\hline 9 & Bidens pachyloma & Major honeybee flower (weed) & In Both watersheds \\
\hline 10 & Medicago polymorpha & Major honeybee flower (weed) & In both watersheds \\
\hline 11 & Guizotia scabra & Major honeybee flower(weed) & In Sasiga and sagure \\
\hline 12 & Guizotia abyssinica & Major honeybee flower and oil crop & In Sagure watershed \\
\hline 13 & Chamecytisus pliferus & Major bee forage and animal feed & In both watersheds \\
\hline 14 & Myrica salicifolia & Fuel, major bee forage plant & In both watersheds \\
\hline
\end{tabular}

\subsection{Attitude toward Improved Beekeeping}

Attitude of beekeepers towards watershed integrated beekeeping technology is a very important phenomenon to take into consideration for sustainable adoption of improved beekeeping in watershed conservation. The beekeepers and stakeholders (district forestry and livestock agency departments) have a sense of positive ownership over the practical beekeeping skills developed and suggested that the technology has to be scaled up, with support from the local government.

It indicated that the majority of the watershed respondents $(87 \%)$ had positive attitude towards watershed integrated beekeeping and honey production. However, $13 \%$ of the respondents had neutral attitude and none of the respondents had negative attitude towards the technology in the study area. The growing knowledge of honeybee management practices in improved beekeeping increased honey production by three fold compared to traditional hives of same colony. This is because the knowledge and skill developed on improved beekeeping is an indication that the beekeeper knows and understands the procedure of obtaining honeybees in a manageable improved hive and manage the colony regularly depending up on the seasonal fluctuation of honeybee forage for maximum honey production. The project has also empowered women, as $15 \%$ of them were engaged in honey production, and have also been employed in selling organic honey products.

\section{Discussion and Conclusion}

Past conservation efforts in Ethiopia have only concentrated in developing watershed conservation programs without addressing the socioeconomic of watershed communities. Community ownership and participation in conservative initiatives is critical to sustainable conservation of watersheds (Lietaer, 2009). Therefore, integrating improved beekeeping technologies and natural resources development offers a pathway that guarantees sustainable watershed management. It is common knowledge that beekeeping is dependent on natural resources and therefore any effort to improve beekeeping in watershed areas, should be hand in hand with the natural resources development.

The project demonstrated the benefits of improved beekeeping for watershed communities, as opposed to illegal logging of watershed. As long as organic honey production continues to be a source of income for watershed producers, the beekeeping user group able to sustain its positive environmental and socio-economic impacts of honeybee. It is beekeeper's long-term interest to regenerate floral species and maintained tree remnants in their homesteads and other sites (Bhusal, and Thapa, 2005). Watershed members are increasingly more aware of the benefits of conserving their watershed environment. They value and retain watershed areas with native bee flora and actively pursue a tree planting on their own properties through selecting suitable species for the long-term 
prospects of providing a resource for honey bees.

Many countries introduced improved beekeeping as reforestation incentives, paying special attention to plant flowering trees that provide nectar and pollen whilst generating income for local communities from bee products (FAO, 2003; Steffan and Kuhn, 2003; Decourtye, et al, 2010; Chazovachii et al, 2012). This consequently led to the creation of reserves around beekeepers homesteads that would be protected and managed by beekeepers to provide them with a strong incentive to maintain and manage watersheds. Evidence from research suggested that traditional beekeepers have a clear financial gain from protecting watershed and they valuing the watershed through measuring the income earned from the sales of honey.

The value of nectar and pollen source plants is highly respected by watershed beekeepers to enhance honey production and improved income of beekeepers. Honey harvesting from improved hives is an income generation activity for small land marginal farmers, landless and living in the watershed that have a great potential for increasing the production of agricultural and horticultural crops thus maintaining biological diversity of watershed.

Beekeepers who kept their own improved hives increased the production of honey by three fold and increased their income also. Beekeeping is a practical tool for raising an awareness of the communities to manage watersheds and could favor watershed conservation (Alemtsehay, 2011 Albersand and Robinson, 2011). The products of the beehives (honey, beeswax, pollen and propolis) are a rich source of nutrients and can be of world quality, and for which there are significant local and international markets (Lietaer, 2009). These activities are not only generating income from sale of honey for watershed user group but also able to sustain the resources through tree plantation, access to improved beekeeping technologies and expensive bee equipment.

The one major factor with a greater capacity to affect the long-term practicability of the improved beekeeping is the increasing of suitable floral resources that consistently produce sustainable pollen and nectar vital for the survival and productivity of a honeybee (Albers and Robinson, 2011). The management of non-cropped farmlands designed to introduce floral resources of honeybees and sustain beekeeping activities. Beekeepers becoming aware of how bees interact in the local environment and there is a potential for greater environmental awareness and an increased incentive to alter activities so as to reduce deforestation and increase plantation using bee forage species (Thuiller et al., 2005; Maddison, 2006; Melaku et al, 2013). The agro-forestry system developed in watershed areas provided ample opportunities for honeybees to forage, with room to preserve and encourage beekeepers to produce more honey in the vicinity of their farms. The project promoted sustainable tree-planting integrated with improved beekeeping to rehabilitate watersheds and generate income from honeybee product for the local community. Experiences in study areas showed that improved beekeeping technology is easily adaptable to local circumstances and easily uptake in watershed communities and recognized the symbiotic relationship between beekeeping and watershed rehabilitation.

The project created a platform for conservationist, district and zonal officials to work together with local communities to produce an integrated watershed management system that ensure sustainable income generation from harvest of organic honey. All stakeholders have a sense of positive ownership over the skills developed, if the technology is to be scaled up, with support from the government influenced policy makers to link integrated watershed conservation with economic development from honey production. The watershedbeekeeping integration technology employed in Sasiga and Sagure watersheds were highly successful. The watershed user group beekeepers transferred using workshops and knowledge exchanges among watershed communities, which were able to share their experiences and provided evidence of the viability of improved beekeeping and honey production.

In conclusion, government should organize landless people in watershed by providing them with the necessary inputs, beekeeping technologies and skills needed to watershed beekeepers to ensure maximum honey production to enhance watersheds income. Conservationists are also required to embark integrated watershed conservation in order to provide adequate information on improved technologies of beekeeping for the producers.

\section{Acknowledgements}

The author is thankful to Holeta Bee research Center and Agriculture Sector Support Project (ASSP) for providing required facilities and logistics. My sincere thanks also extended to Dejene Takele, Gete Daba, Getu Gudeta and Hiyiwot Birhanu for their inspiration and support in the implementation and follow-up of the research. I am thankful to all the watershed user groups and partners for their contribution towards this successful of the project. ASSP under Oromiya Agricultural Bureau is funding this project.

\section{References}

[1] Adugna, W. 2002. Genetic diversity analysis of linseed under different environments. $\mathrm{PhD}$ thesis, Department of Plant Breeding, Faculty of Agric. Univ. of the Free State, Bloemfontein, South Africa.

[2] Albers, H.J. and Robinson, E.J. 2011. The trees and the bees: using enforcement and income projects to protect forests and rural livelihoods through spatial joint production. Agricultural and resource economics review 40/3: 424-438.

[3] Alemtsehay, T. 2011. Seasonal availability of common bee flora in relation to land use and colony performance in Gergera watershed Atsbi Wembwrta District Eastern Zone of Tigray, M.Sc Thesis, Wondo Genet College of Forestry, School Of Graduate Studies, Hawasa University, Hawassa, Ethiopia 
[4] Bhusal, S. J. and Thapa, R. B. 2005. Comparative study on the adoption of improved beekeeping technology for poverty alleviation. J. Inst. Agric. Anim. Sci. 26:117-125.

[5] Bradbear, N. 2009. Bees and their role in forest livelihoods: A Guide to the Services Provided by Bees and the Sustainable Harvesting, Processing, and Marketing of Their Products. Food and Agriculture Organization, Rome.

[6] Brown, C. 2001. Responding to deforestation: Productive conservation, the World Bank, and beekeeping in Rondonia, Brazil. The Profess. Geog., 53(1):106-119.

[7] Debisa, L. 2006. The Roles of Apiculture in Vegetation Characterization and Household Livelihoods in Walmara District, Central Ethiopia. M.sc. Thesis, Wondo Genet College of Forestry, School Of Graduate Studies, Hawasa University, Hawassa, Ethiopia

[8] Decourtye, A; Mader, E. \& Desneux, N. 2010. Landscape enhancement of floral resources for honey bees in agroecosystems. Apidologie, Vol.41, pp. 264-277.

[9] FAO, 2003. State of the World's Forests. Food and Agriculture Organization of the United Nations, Rome.

[10] Holzschuh, ASteffan-Dewenter, I. Kleijn, D. and Tscharntke, T. 2007. Diversity of flower-visiting bees in cereal fields: Effects of farming system, landscape composition and regional context. Journal of Applied Ecology: 44: 41-49.

[11] Lietaer, C. 2009. Impact of beekeeping on forest conservation, preservation of forest ecosystems and poverty reduction. XIII World Forestry Congress, 18 - 23, Argentina.

[12] Maddison, D. 2006. The perception and adaptation to climate change in Africa. CEEPA. Discussion Paper No. 10. Centre for Environmental Economics and Policy in Africa, University of Pretoria, South Africa.

[13] Melaku, B., Girmay, M. and Bereket, G. 2013. Identifying beekeepers' adaptation strategies in response to climate change in Tigray, Ethiopia Wudpecker Journal of Agricultural Research Vol. 2(5: 155 - 159

[14] Munthali S.M. and Mughogho. D. E. 1992. Economic incentives for conservation: beekeeping and Saturniidae caterpillar utilization by rural communities. Biodiversity and Conservation 1:143-154.

[15] Paraïso, A., Sossou, A., IZ-haquou, D., Yegbeme,Y. R. and Sanni, A. 2012. Perceptions and adaptations of beekeepers and honey hunters to climate change: The case of the communes of Natitingou and Tanguieta in Northwest of Benin. African Crop Science Journal, Vol. 20, Issue Supplement s2, pp. 523 - 532.

[16] Porter-Bolland, L. 2001. Landscape ecology of apiculture in the Maya area .A dissertation presented to the graduate school of the university of Florida in partial fulfillment of the requirements for the degree of Doctor of Philosophy, University of Florida.

[17] Saville, N. and Upadhaya, S.N., 2000. Indigenous knowledge of beekeeping in Jumla, Western Nepal." In Asian Bees and Beekeeping: Progress of Research and Development. (Eds: Matsuka, M. et al.) pp. 248 - 251. New Delhi: Oxford and IBH.

[18] Somerville, D. 1997. Beekeeping in the Mildura Forestry Management Area. NSW Agriculture, Goulburn.

[19] Steffan-Dewenter, I. and Kuhn, A. 2003. Honeybee foraging in differentially structured landscapes. Proceedings of the Royal Society of London Series B-Biological Sciences, Vol. 270 pp. 569-575.

[20] Thuiller, W., Lavorel, S., Araujo, M.B., Sykes, M.T. and Prentice, I.C. 2005. Climate change threats to plant diversity in Europe. Proceedings of National Academy of Sciences USA, $102(23): 8245-8250$ 